\title{
A Water Footprint Review of Italian Wine: Drivers, Barriers, and Practices for Sustainable Stewardship
}

\author{
Eirini Aivazidou 1,2,*(D) and Naoum Tsolakis $1,3,4$ (D) \\ 1 Laboratory of Statistics and Quantitative Analysis Methods (LASCM), Department of Industrial \\ Management, School of Mechanical Engineering, Aristotle University of Thessaloniki, 54124 Thessaloniki, \\ Greece; nt377@cam.ac.uk \\ 2 Department of Computer Science and Engineering (DISI), School of Engineering, Alma Mater \\ Studiorum-University of Bologna, 40126 Bologna, Italy \\ 3 Centre for International Manufacturing, Institute for Manufacturing (IfM), Department of Engineering, \\ School of Technology, University of Cambridge, Cambridge CB3 0FS, UK \\ 4 Institute for Bio-Economy and Agri-Technology (iBO), Centre for Research and Technology-Hellas (CERTH), \\ 57001 Thessaloniki, Greece \\ * Correspondence: aveirini@auth.gr
}

Received: 21 December 2019; Accepted: 25 January 2020; Published: 29 January 2020

check for updates

\begin{abstract}
Wine constitutes the dominant Italian agricultural product with respect to both production quantity and economic value. Italy is the top wine producer worldwide in terms of volume and the second one below France in terms of national income. As the Italian agricultural production accounts for $85 \%$ of the national freshwater appropriation, the country's agricultural sector strains freshwater resources, especially in the central and southern regions, which constitute important winemaking areas in terms of quantity and quality. To this end, we first perform a review of the existing research efforts on wine water footprint assessment to investigate the water dynamics of wine production in Italy compared to the rest of the world. The results indicate a prevalence of studies on the water footprint of Italian wine, emphasising the need for deeper research on the sector's water efficiency. Then, we aim at exploring the major drivers, barriers, and good practises for systematic water stewardship in the Italian winemaking industry, considering the product and territorial characteristics. This research is anticipated to contribute towards providing insights for practitioners in the Italian wine sector to develop water-friendly corporate schemes for enhancing the added value of their products.
\end{abstract}

Keywords: freshwater resources; water footprint; water management; wine production; winemaking sector; Italy

\section{Introduction}

The winemaking industry plays a critical role in the economy of the primary sector of the Southern European and Mediterranean regions [1]. Thus, there is an increased pressure towards minimising the environmental impacts of wine production [2] to improve the sustainability of the sector in terms of climate change and natural resources [3]. More specifically, consumers' environmental expectations further motivate winemakers to adopt green technological interventions for efficient water use during irrigation or wastewater reuse [4]. In addition, given that a considerable number of consumers, especially young ones [5], express willingness to pay a premium for a sustainable wine label [6], the production of water-friendly wine could be an ambitious strategy for increasing profitability through quality improvement [7].

The winemaking efficiency in terms of freshwater use can be expressed through the water footprint (WF) concept, which refers to the total volume of freshwater consumed and polluted at national, 
corporate, or product levels [8]. Specifically, WF is a multidimensional indicator that consists of three components: (i) green water addresses the absorption of rainwater by plants (i.e., the proportion of precipitation that infiltrates into the unsaturated soil zone and is temporarily stored in soil and vegetation canopy [9]), (ii) blue water refers to the consumption of surface or groundwater during irrigation and processing activities, and (iii) grey water constitutes the freshwater quantity used for assimilating pollutants during farming and manufacturing given specific water quality standards [8].

In Italy, agricultural production is responsible for $85 \%$ of the country's freshwater appropriation (This percentage is calculated as the ratio of the WF of crop production, grazing, and animal water supply to the total WF of national production in Italy, which are both provided in annual average values during the reference period 1996-2005), of which $81 \%$ refers to green $\mathrm{WF}, 8 \%$ refers to blue WF, and $11 \%$ refers to grey WF [10]. In the case of the winemaking sector, the average WF of Italian grapes equals to $488 \mathrm{~L}$ per $\mathrm{kg}$ of fresh fruit, of which $76 \%$ corresponds to green water, $7 \%$ corresponds to blue water, and $17 \%$ corresponds to grey water [11]. In terms of wine, the average WF of a glass $(0.125 \mathrm{~L})$ of Italian wine is $88 \mathrm{~L}$ [12]. Notably, a considerable number of research papers further quantify the WF of different wine varieties across the regions of the country. Apart from water use, emphasis is further placed on water scarcity issues of the Italian territory. In fact, the national agricultural sector poses considerably high stress on freshwater resources [13], particularly in Southern Italy [14], which constitutes an important winemaking area in terms of wine quantity and quality [15].

Although the water impact of wine is relatively low compared to other agricultural commodities [11], its high production volume and its economic value in Italy render research on the WF of Italian wine essential. In fact, wine constitutes the top national agricultural product in terms both of quantity and value [16]. Compared to the rest of the world in 2017, Italy constituted the first producer concerning wine volume (4.25 billion L, excluding juice and must) [1], and the second one below France regarding economic value (12.1 billion Euro) [17]. In addition, the country came third following the United States and France ( 2.26 billion L) in respect to wine consumption, while it was second both below Spain in terms of export volume (2.14 billion L) and below France concerning export value (5.87 billion Euro) [1].

Notably, scientific research on the WF assessment of wine is growing rapidly [18]. As water management across supply chains is considered as vital for the long-term sustainability of the winemaking industry [19], this work aims at (i) reviewing the existing WF assessment efforts during wine production to explore how the wine WF research is diffused worldwide (Section 2), (ii) investigating the drivers and barriers of water stewardship in the Italian winemaking sector as an identified global leader in the field of study (Section 3), and (iii) discussing water stewardship policies applicable to the Italian wine production (Section 4). Overall, this paper aims at highlighting the need for water management in the wine industry, especially in water-scarce countries where it constitutes a major economic activity. To this end, we anticipate that this research will contribute towards supporting winemaking practitioners in identifying good practices in water management and launching efficient water-related corporate schemes through overcoming barriers motivated by impelling drivers.

\section{Water Footprint of Wine: Literature Background}

In this section, we perform a review of the global wine WF literature to identify the position of the Italian case studies in this research field. Within the extant literature, we have identified 20 articles in total that include the terms "water footprint" (or "water management" or "freshwater resources") and "wine" (or "winemaking") in the Scopus and Web of Science databases. Then, we present the major descriptive statistics of the review findings along with a brief discussion. Finally, the taxonomy of the Italian literature provides a detailed analysis of the papers under study in a structured manner.

The WF of a product is defined as the total volume of freshwater used directly or indirectly across its end-to-end supply chain [20]. Figure 1 illustrates the different stages of a wine supply chain, highlighting the viticulture and the vinification phases as the prevalent WF contributors. To quantify the WF of wine, several methodological approaches exist; the WF assessment manual that focusses on 
the volumetric measurement of water consumption and pollution [8] and the life cycle assessment (LCA) techniques (e.g., the ISO 14046 [21]), further including the impact of water scarcity (which varies spatially and temporally) on the WF indicator [14], constitute the most common ones. Although a comparison among the different WF assessment approaches is considered out of the scope of this research, a more detailed analysis of their unique charasterics is provided by Chenoweth et al. [22].

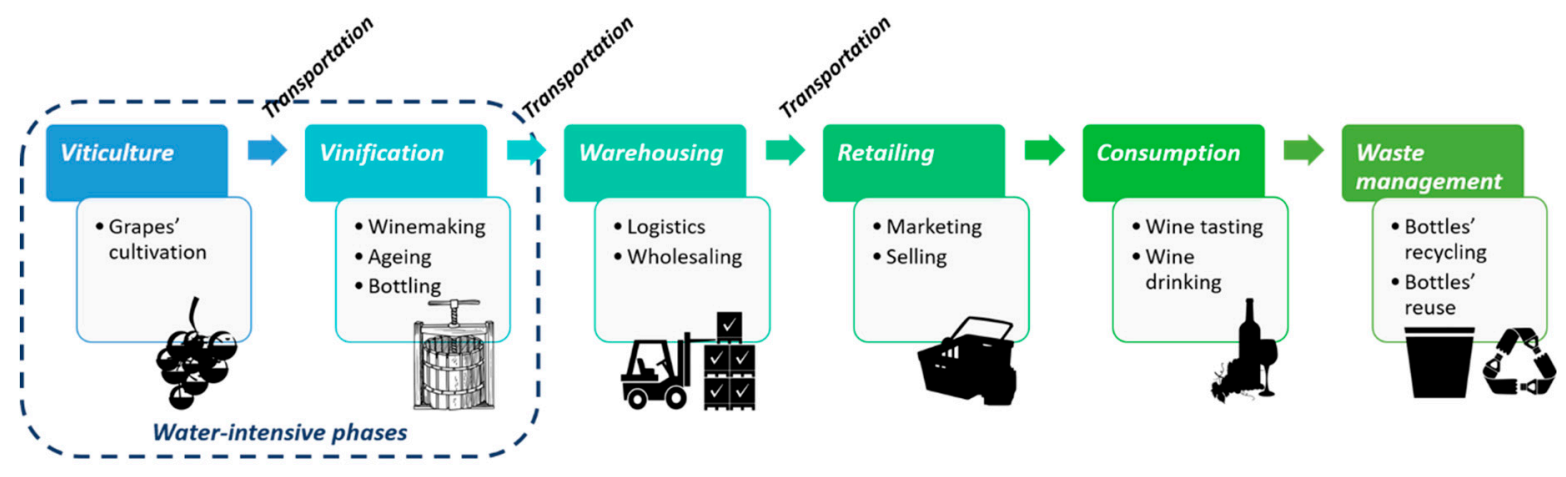

Figure 1. Typical wine supply chain.

\subsection{Research Efforts Worldwide}

Several case studies on wine WF assessment have been identified in the literature, indicating the increasing academic interest in evaluating the use of freshwater resources in the winemaking sector worldwide. Outside Europe, efforts have been made to quantify the WF of New Zealand's wines. First, a combination of an LCA-based approach and a hydrological water-balance technique was implemented to quantify the volume of water consumed and polluted during wine production in two New Zealand regions [23]. In a later study, the authors extended the WF research of New Zealand's wine by comparing the results obtained using diverse methodologies, further including the traditional WF assessment method, to investigate freshwater utilisation from different perspectives [24]. In North America, a US study assessed the greenhouse gas emissions, the energy use, and the freshwater use across the life cycle of wine produced in California, beginning from the cultivation of grapes up to their delivery at the winery gate, to provide a holistic evaluation of the wine's environmental impact [25]. Moreover, a preliminary research effort was made for assessing the grey WF associated with wastewater produced during the winemaking process in a Canadian winery and co-treated by municipal wastewater treatment plants [26]. In Latin America, a recent study quantified the consumptive blue and green WF of several varieties of grapes for wine production in five Argentinian regions, using different irrigation systems [27].

Within Europe, although the majority of research on wine WF assessment has been documented across southern countries, two publications refer to Northern Europe. In Romania, the WF of a bottled wine produced in a medium-sized winemaking plant was quantified in the stages of viticulture and vinification, further evaluating the socio-economic potential of winemaking and the related water-related schemes within the country [28]. In Hungary, a recent study developed a framework for WF assessment during grapes' cultivation and processing to optimise the consumption of both rainwater and freshwater consumed [29]. Moving to the south, several researchers evaluated the WF of Iberian wines. More specifically, an evaluation of both direct and indirect freshwater use was performed for a Portuguese white wine variety during the viticulture and the winemaking stages, further analysing the related environmental impacts of water use [30]. In addition, a more comprehensive analysis included the LCA of the carbon, water, and energy footprints, as well as the material intensity and solid and water wastes, of a bottle wine during the phases of grapes' cultivation, wine production, bottling and packaging in Portugal [31]. More recently, the water-related ISO 14046 was used to analyse the WF profile of a Spanish grape variety for vinification and to address the impacts due to water scarcity and degradation from a life cycle perspective [32]. Moreover, an indicator 
of water depletion, mainly due to irrigation during the viticulture stage, was evaluated in the context of a complete LCA of an aged red wine produced in Catalonia, Spain [33].

\subsection{Italian Case Studies}

An increased number of case studies on wine WF has been mapped across the Italian territory. Lamastra et al. [34] proposed a new WF quantification approach (Valutazione Impatto Viticoltura sull'Ambiente - V.I.V.A. tool) to improve the WF assessment manual technique [8], emphasising in detail the calculation of the grey WF of six different wine varieties of a Sicilian winery. Bonamente et al. [35] quantified the direct green, blue, and grey WFs of a typical red wine produced from a blend of grape varieties by a medium-sized winery in Umbria, based on the V.I.V.A. tool [34] and following the ISO 14046 principles [21]. In a later study, the authors performed a combined carbon and WF assessment in the life cycle of the Italian red wine using the same dataset and methodological approach [36]. In the same vein, Rinaldi et al. [37] performed a cradle-to-grave analysis for juxtaposing the carbon and WF indicators of a red and a white wine of an Umbrian producer, using the same system boundaries, functional unit, and input data, based on the relevant ISO guidelines [21]. In Umbria again, Bartocci et al. [38] calculated the carbon, ecological, and WF, along with several LCA-related environmental impacts, for two different varieties of grapes during cultivation, wine production, vinegar ageing, and bottling, following the ISO approach [21]. Recently, Borsato et al. [39] compared the WF outcomes of a volumetric (i.e., the V.I.V.A. tool [34]) and two LCA-based approaches (i.e., Available WAter REmaing - AWARE [40] and Water Scarcity Index [14]) during the production of a white wine variety in Northeast Italy to improve water management. Miglietta et al. [41] investigated the WF of two types of wines indicated with designation of origin whose vineyards are situated in Northern (Piedmont) and Southern (Sicily) Italy to compare the geographical impact of grapes' cultivation on freshwater consumption and pollution. More recently, Miglietta et al. [42] quantified the water efficiency (i.e., the ratio of total wine WF to total wine production) and the economic water productivity (i.e., the ratio of wine price to wine WF) of all Italian wines indicated with appellation of origin. In addition, Miglietta and Morrone [43] studied the virtual water flows and economic water productivity of wine trade between Italy and Balkan countries. The latter three research efforts were conducted based on the WF assessment manual estimates [8].

Figure 2 illustrates the distribution of the case studies on wine WF assessment by country. Notably, Italy dominates the wine WF research (i.e., nine out of 20 studies), confirming (i) the leading role of the Italian winemaking industry both within the country [16] and abroad [1], and (ii) the increased water scarcity concerns in the region [14], followed by New Zealand, Portugal, and Spain (i.e., two out of 20 studies each). Notably, there is an apparent absence of WF studies for French wines, despite the major economic impact of the country's winemaking sector worldwide [17], which is potentially due to lower water scarcity indices compared to Italy [14]. In addition, Figure 3 depicts the distribution of the studies by year of publication. In fact, the research on wine WF assessment has received a rather constant interest during the last 6.5 years (i.e., the first paper was identified in 2013), exhibiting an average of 2.9 studies per year worldwide and 1.2 studies annually in Italy.

Finally, Table 1 provides a taxonomy of the literature in the field of wine WF assessment in Italy. More specifically, the type of the study, the period in which the data were collected, the location of the study, the wine variety examined, the winemaking phase considered, the WF assessment method used, as well as the type and volume of the WF quantified, are documented to provide detailed information in the field of wine WF assessment in a supplementary manner. Notably, a comparative analysis of the studies could be challenging due to significant differences concerning the (i) methodological approaches implemented, (ii) databases utilised, (iii) assumptions articulated, and (iv) temporal or spatial characteristics considered. However, as the diverse WF assessment approaches exhibited vary with respect to the manner that they quantify water use [22], it is not infeasible to compare WF results derived from different methods, even though the calculations are performed using the same dataset [44]. In fact, Bonamente et al. [36] confirm this statement through providing different results 
compared to Bonamente et al. [35], although they use the same input data. Even by applying the same methodology, the different wine variety types [34], as well as the diverse climatic and geographical conditions of the Italian regions from North to South [41], influence the wine WF assessment findings. Nevertheless, in general, green water emerges as the typical source of water for wine production, even in semi-arid environments such as Central Italy.

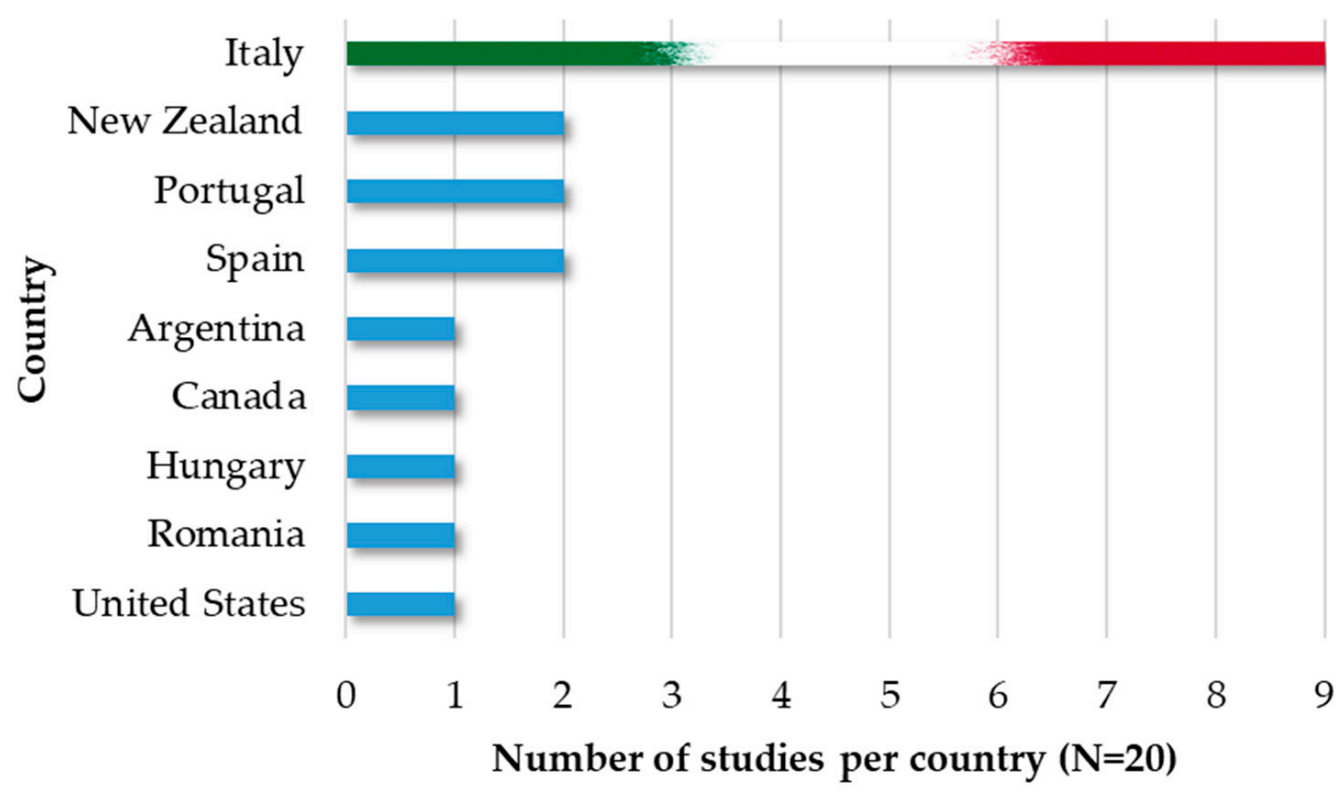

Figure 2. Distribution of studies on wine WF assessment by country.

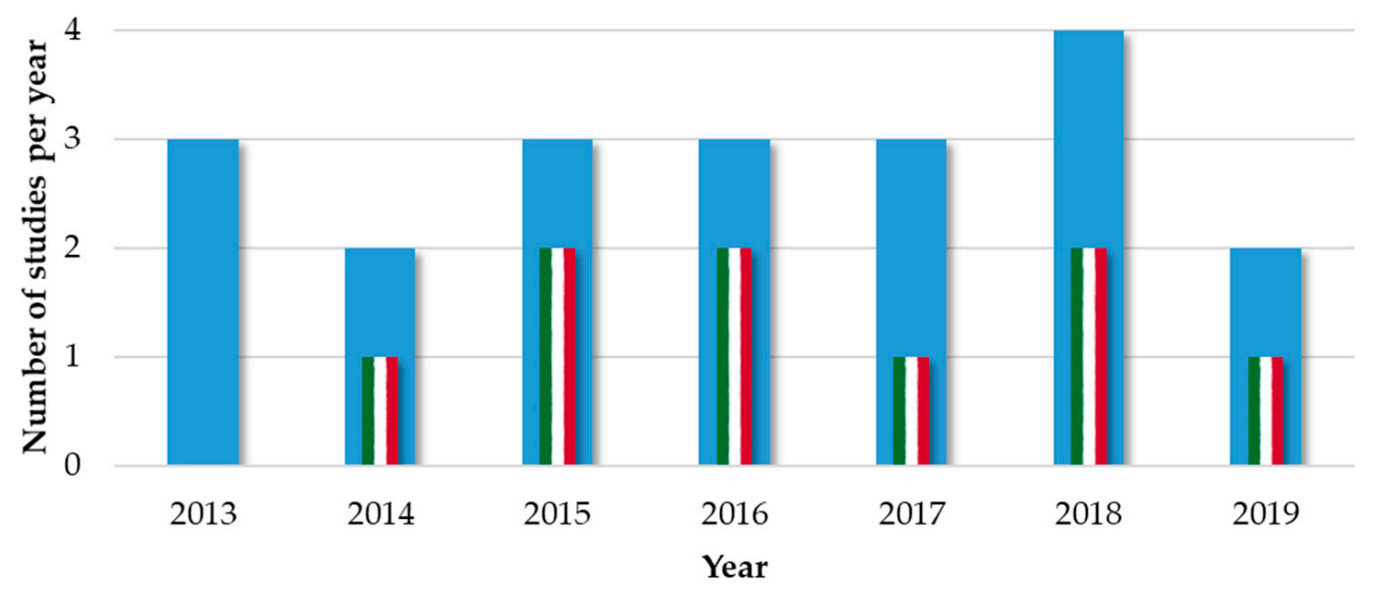

All studies $(\mathrm{N}=\mathbf{2 0}) \quad$ II Italian studies $(\mathrm{N}=9)$

Figure 3. Distribution of studies on wine WF assessment by year. 
Table 1. Taxonomy of wine WF research in Italy.

\begin{tabular}{|c|c|c|c|c|c|c|c|c|c|}
\hline \multirow{2}{*}{ Reference } & \multirow{2}{*}{ Study Type } & \multirow{2}{*}{ Study Period } & \multirow{2}{*}{ Location } & \multirow{2}{*}{ Wine Variety } & \multirow{2}{*}{$\begin{array}{l}\text { Winemaking } \\
\text { Phase }\end{array}$} & \multirow{2}{*}{$\begin{array}{l}\text { WF Assessment } \\
\text { Method }\end{array}$} & \multicolumn{3}{|c|}{ WF Type and Volume } \\
\hline & & & & & & & Green & Blue & Grey \\
\hline $\begin{array}{l}\text { Lamastra et al. } \\
{[34]}\end{array}$ & $\begin{array}{l}\text { Real case } \\
\text { study }\end{array}$ & Not specified & $\begin{array}{c}\text { Province of } \\
\text { Palermo, Region of } \\
\text { Sicily }\left(13.49^{\circ} \mathrm{N},\right. \\
\left.13.51^{\circ} \mathrm{E}\right)\end{array}$ & $\begin{array}{c}\text { Cabernet Sauvignon; } \\
\text { Chardonnay; Nero } \\
\text { d'Avola; White Pinot; } \\
\text { Grecanico }\end{array}$ & $\begin{array}{l}\text { Viticulture; } \\
\text { Vinification }\end{array}$ & $\begin{array}{c}\text { WF assessment } \\
\text { manual [9]; V.I.V.A. } \\
\text { tool [34] }\end{array}$ & $\begin{array}{c}\text { 694.5-902.9 (WF } \\
\text { manual); } \\
\text { 689.5-915.9 (V.I.VA.) } \\
\text { L/L of wine }\end{array}$ & $\begin{array}{l}\text { 2.6-42.5 L/L of wine } \\
\text { (Same for both } \\
\text { methods) }\end{array}$ & $\begin{array}{c}\text { 0-228.6 (WF } \\
\text { manual); 0-389.8 } \\
\text { (V.I.V.A) L/L of wine }\end{array}$ \\
\hline $\begin{array}{l}\text { Bonamente et al. } \\
\quad[35]\end{array}$ & $\begin{array}{l}\text { Real case } \\
\text { study }\end{array}$ & 2012 & Region of Umbria & $\begin{array}{l}\text { Sangiovese with small } \\
\text { percentages of Merlot } \\
\text { and Cabernet Sauvignon }\end{array}$ & $\begin{array}{l}\text { Viticulture; } \\
\text { Vinification }\end{array}$ & $\begin{array}{l}\text { V.I.V.A. tool [34]; } \\
\text { ISO 14046 [21] (only } \\
\text { as a framework) }\end{array}$ & $\begin{array}{l}621.4 \mathrm{~L} / \mathrm{bottle} \text { of } \\
0.75 \mathrm{~L}\end{array}$ & $3.4 \mathrm{~L} /$ bottle of $0.75 \mathrm{~L}$ & $7.4 \mathrm{~L} /$ bottle of $0.75 \mathrm{~L}$ \\
\hline $\begin{array}{l}\text { Bonamente et al. } \\
\quad[36]\end{array}$ & $\begin{array}{l}\text { Real case } \\
\text { study }\end{array}$ & 2012 & Region of Umbria & $\begin{array}{l}\text { Sangiovese with small } \\
\text { percentages of Merlot } \\
\text { and Cabernet Sauvignon }\end{array}$ & $\begin{array}{l}\text { Viticulture; } \\
\text { Vinification }\end{array}$ & ISO 14046 [21] & $\begin{array}{l}450.6 \mathrm{~L} / \mathrm{bottle} \text { of } \\
0.75 \mathrm{~L}\end{array}$ & $7.1 \mathrm{~L} /$ bottle of $0.75 \mathrm{~L}$ & $\begin{array}{l}120.4 \mathrm{~L} / \text { bottle of } \\
0.75 \mathrm{~L}\end{array}$ \\
\hline $\begin{array}{l}\text { Rinaldi et al. } \\
\quad[37]\end{array}$ & $\begin{array}{l}\text { Real case } \\
\text { study }\end{array}$ & 2012 & Region of Umbria & $\begin{array}{l}\text { Red wine; white wine } \\
\text { (specific variety not } \\
\text { specified) }\end{array}$ & $\begin{array}{l}\text { Viticulture; } \\
\text { Vinification }\end{array}$ & ISO 14046 [21] & $\begin{array}{c}450.6 \text { (red); } 496.6 \\
\text { (white) L/bottle of } \\
0.75 \mathrm{~L}\end{array}$ & $\begin{array}{l}10 \text { (red); } 9.8 \text { (white) } \\
\text { L/bottle of } 0.75 \mathrm{~L}\end{array}$ & $\begin{array}{c}43.5 \text { (red); } 44.6 \\
\text { (white) L/bottle of } \\
0.75 \mathrm{~L}\end{array}$ \\
\hline $\begin{array}{l}\text { Bartocci et al. } \\
\quad[38]\end{array}$ & $\begin{array}{l}\text { Real case } \\
\text { study }\end{array}$ & 2012 & $\begin{array}{l}\text { Province of Perugia, } \\
\text { Region of Umbria }\end{array}$ & Grechetto; Sarantino & $\begin{array}{l}\text { Viticulture; } \\
\text { Vinification }\end{array}$ & ISO 14046 [21] & $\begin{array}{c}830 \text { (Grechetto); } 592 \\
\text { (Sarantino) L/L of } \\
\text { vinegar }\end{array}$ & $\begin{array}{l}446 \text { (Grechetto); } 301 \\
\text { (Sarantino) L/L of } \\
\text { vinegar }\end{array}$ & $\begin{array}{c}616 \text { (Grechetto); } 439 \\
\text { (Sarantino) L/L of } \\
\text { vinegar }\end{array}$ \\
\hline \multirow[t]{2}{*}{$\begin{array}{l}\text { Borsato et al. } \\
\quad[39]\end{array}$} & \multirow[t]{2}{*}{$\begin{array}{l}\text { Real case } \\
\text { study }\end{array}$} & \multirow[t]{2}{*}{2017} & \multirow{2}{*}{$\begin{array}{l}\text { Northeast Italy } \\
\left(45.87^{\circ} \mathrm{N}, 12.70^{\circ} \mathrm{E}\right)\end{array}$} & \multirow[t]{2}{*}{$\begin{array}{l}\text { White wine (specific } \\
\text { variety not specified) }\end{array}$} & \multirow{2}{*}{$\begin{array}{l}\text { Viticulture; } \\
\text { Vinification }\end{array}$} & \multirow{2}{*}{$\begin{array}{l}\text { V.I.V.A. tool [34]; } \\
\text { AWARE [40]; Water } \\
\text { Scarcity Index [14] }\end{array}$} & $\begin{array}{l}0.988 \mathrm{~m}^{3} / \text { bottle of } \\
0.75 \mathrm{~L} \text { (V.I.V.A.) }\end{array}$ & $\begin{array}{l}0.181 \mathrm{~m}^{3} / \text { bottle of } \\
0.75 \mathrm{~L} \text { (V.I.V.A.) }\end{array}$ & $\begin{array}{l}0.024 \mathrm{~m}^{3} / \text { bottle of } \\
0.75 \mathrm{~L} \text { (V.I.V.A.) }\end{array}$ \\
\hline & & & & & & & \multicolumn{3}{|c|}{$\begin{array}{c}1.44 \text { (AWARE); } 0.01 \text { (Water scarcity index) } \mathrm{m}^{3} / \text { bottle of } 0.75 \mathrm{~L} \mathrm{(Nc} \\
\text { type categorisation) }\end{array}$} \\
\hline $\begin{array}{l}\text { Miglietta et al. } \\
{[41]}\end{array}$ & $\begin{array}{c}\text { Secondary } \\
\text { data analysis }\end{array}$ & Not specified & $\begin{array}{l}\text { Region of Piedmont; } \\
\text { Region of Sicily }\end{array}$ & $\begin{array}{l}\text { Barolo; Moscato di } \\
\text { Pantelleria }\end{array}$ & Viticulture & $\begin{array}{c}\text { WF assessment } \\
\text { manual [8] }\end{array}$ & \multicolumn{3}{|c|}{$487-548 \mathrm{~L} / \mathrm{L}$ of wine (Sum of all types) } \\
\hline $\begin{array}{l}\text { Miglietta et al. } \\
\text { [42] }\end{array}$ & $\begin{array}{c}\text { Secondary } \\
\text { data analysis }\end{array}$ & 2011-2015 & $\begin{array}{l}\text { Whole Italian } \\
\text { territory }\end{array}$ & $\begin{array}{c}65 \text { varieties with } \\
\text { appellation of origin }\end{array}$ & Viticulture & $\begin{array}{c}\text { WF assessment } \\
\text { manual [8] }\end{array}$ & \multicolumn{3}{|c|}{$3.03-6.68 \mathrm{~m}^{3} / \mathrm{ha}$ of vineyard (sum of all types) } \\
\hline $\begin{array}{l}\text { Miglietta and } \\
\text { Morrone [43] }\end{array}$ & $\begin{array}{l}\text { Secondary } \\
\text { data analysis }\end{array}$ & $2007-2016$ & $\begin{array}{c}\text { Whole Italian } \\
\text { territory (Average) }\end{array}$ & All varieties (average) & Viticulture & $\begin{array}{l}\text { WF assessment } \\
\text { manual [8] }\end{array}$ & $460 \mathrm{~m}^{3} /$ ton of wine & $40 \mathrm{~m}^{3} /$ ton of wine & $101 \mathrm{~m}^{3} /$ ton of wine \\
\hline
\end{tabular}




\section{Water Stewardship in the Italian Wine Industry: Drivers and Barriers}

The food and beverage industry's contribution to global freshwater withdrawal is well documented in the extant scientific literature, while freshwater resources are dwindling at an alarming rate [18]. As satisfying the supply of food products requires a sufficient and consistent availability of freshwater resources, collaborative and harmonised interventions across supply chains are essential in order to ensure sustainable and efficient water use [45]. Considering that the Italian wines exhibit substantial WFs especially in water-stressed areas, we discuss the main drivers and barriers of water management in the wine sector based on the existing Italian research efforts. Table 2 summarises the identified drivers and barriers along with a taxonomy of the citing articles.

Table 2. Drivers and barriers of water stewardship in Italy.

\begin{tabular}{|c|c|c|}
\hline Type & Description & References \\
\hline \multirow{7}{*}{ Drivers } & $\begin{array}{l}\text { Linkage between water-related environmental } \\
\text { aspects to space-temporal pressures }\end{array}$ & $\begin{array}{l}\text { Lamastra et al. [34]; } \\
\text { Bonamente et al. [35]; } \\
\text { Miglietta et al. [42]; } \\
\text { Miglietta and Morrone [43] }\end{array}$ \\
\hline & $\begin{array}{c}\text { Global trade and makers' attentiveness to } \\
\text { sustainable wine supplies and } \\
\text { sustainable marketing }\end{array}$ & $\begin{array}{c}\text { Bonamente et al. [35]; } \\
\text { Bartocci et al. [38]; } \\
\text { Borsato et al. [39]; } \\
\text { Miglietta et al. [42]; } \\
\text { Miglietta and Morrone [43] }\end{array}$ \\
\hline & $\begin{array}{l}\text { Consumers' profitable purchasing behaviours } \\
\text { towards sustainable wine supplies, particularly } \\
\text { when linked to particular territorial culture } \\
\text { and history }\end{array}$ & $\begin{array}{l}\text { Bartocci et al. [38]; } \\
\text { Miglietta et al. [42] }\end{array}$ \\
\hline & $\begin{array}{l}\text { Correlation between freshwater quantity/quality } \\
\text { and wine quality }\end{array}$ & $\begin{array}{l}\text { Lamastra et al. [34]; } \\
\text { Miglietta et al. [41] }\end{array}$ \\
\hline & $\begin{array}{l}\text { Proliferation of the literature with studies and } \\
\text { methodologies on water management allowing } \\
\text { for benchmarking }\end{array}$ & $\begin{array}{l}\text { Bonamente et al. [36]; } \\
\text { Rinaldi et al. [37] }\end{array}$ \\
\hline & $\begin{array}{l}\text { Institutional policies and funding schemes } \\
\text { supporting water management initiatives }\end{array}$ & $\begin{array}{l}\text { Borsato et al. [39]; } \\
\text { Miglietta et al. [41] }\end{array}$ \\
\hline & $\begin{array}{l}\text { Production effectiveness deriving from water } \\
\text { stewardship, particularly from an end-to-end } \\
\text { supply chain perspective }\end{array}$ & $\begin{array}{c}\text { Bonamente et al. [36]; } \\
\text { Bartocci et al. [38]; } \\
\text { Miglietta et al. [42]; } \\
\text { Miglietta and Morrone [43] }\end{array}$ \\
\hline \multirow{5}{*}{ Barriers } & $\begin{array}{l}\text { Lack of standardisation of system boundaries to } \\
\text { apply and assess the impact of water } \\
\text { management policies and practises }\end{array}$ & $\begin{array}{l}\text { Bonamente et al. [36]; } \\
\text { Rinaldi et al. [37]; } \\
\text { Borsato et al. [39] }\end{array}$ \\
\hline & $\begin{array}{l}\text { Limited contextualisation of water management } \\
\text { operations, particularly with reference to the } \\
\text { economic water productivities }\end{array}$ & $\begin{array}{l}\text { Lamastra et al. [34]; } \\
\text { Miglietta et al. [42] }\end{array}$ \\
\hline & $\begin{array}{l}\text { Structural and computational diversification of } \\
\text { methodologies assessing the impact of water } \\
\text { management policies and practises }\end{array}$ & $\begin{array}{l}\text { Bonamente et al. [35]; } \\
\text { Bonamente et al. [36]; } \\
\text { Borsato et al. [39]; } \\
\text { Miglietta et al. [41] }\end{array}$ \\
\hline & $\begin{array}{l}\text { Variations in functional characteristics of wine } \\
\text { production setting (e.g., local climatic conditions, } \\
\text { production processes, etc.) }\end{array}$ & $\begin{array}{c}\text { Bonamente et al. [36]; } \\
\text { Borsato et al. [39]; } \\
\text { Miglietta and Morrone [43] }\end{array}$ \\
\hline & $\begin{array}{l}\text { Proliferation of eco-labelling options limiting } \\
\text { business differentiation possibilities }\end{array}$ & Miglietta and Morrone [43] \\
\hline
\end{tabular}




\subsection{Drivers}

From an environmental point of view, the elevated global water stress levels foster the adoption and application of water management policies and practices in the wine industry [19]. More specifically, wine quality is correlated to grapes' quality, thus motivating the wine industry to investigate irrigation practises [34]. In particular, a wine's identify is defined by grape maturation, aroma, and coloration [46], which are attributes that are amenable to the vine's geographical location and climate conditions that determine the chemical composition and sensory characteristics of grapes [47].

As freshwater appropriation is characterised by space-temporal dimensions, the adoption of advocated practises in the winemaking industry is eminent to mitigate water stress phenomena at both local and global freshwater bodies $[33,35,43]$. This need is even more pronounced in regions where the nexus of water scarcity, vineyards, production seasonality, and climatic conditions' severity aggravate water consumption. In this regard, targeted institutional and state-specific policies and directives (e.g., European Program of Sustainability, New Zealand Winegrowing Program, Italian initiative on Valutazione dell' Impatto in Vitivinicoltura sull' Ambiente) motivate circular economy and water-use minimisation in wine [39], while they further support investments in related infrastructure to protect water quality and quantity [41]. Furthermore, the plethora of research studies and corporate reports pertinent to water consumption across the wine supply chains operations allows benchmarking [36,37], thus further enabling the continuous improvement and proliferation of water management policies and practises among industry stakeholders.

From a socio-economic angle, water security has a prominent role in the United Nations Sustainable Development Goals, as it is recognised as a key determinant to the delivery of a viable ecosystem to future generations and a critical factor towards ensuring continuity to food manufacturing operations [48]. In particular, securing freshwater resources' sustainability allows winegrowers to improve economic water productivity of their wine supply chains (i.e., monetary value attained per cubic meter of water used), hence ensuring high-quality winery products at a low level of water use [42]. In addition, the implementation of water management policies and practises (e.g., water reuse) allows grape growers and wine manufacturers to reduce the resources' scarcity burden linked with their production $[35,36]$. To a greater extent, reducing the utilisation of freshwater as a production material results in operational cost savings for companies [43].

From a market perspective, consumers' awareness and attentiveness over the sustainability impact of wine products drive demand growth in the sector, especially in case water-related eco-certification is provided [39]. Indicatively, Rugani et al. [49] critically analysed LCA and carbon footprint-based studies on the wine-making industry and stressed that carbon footprint labelling in wines provides a market differentiation element that could influence consumers' purchasing behaviour. Moreover, wine produced with sustainable techniques has a greater export potential [42], while customers have a willingness to pay a premium price for environmentally friendly wine products [38]. Specifically, given that around $80 \%$ of wine sales occur in-store, clear communication of sustainably produced wine is deemed critical for increasing sales [50]. Therefore, as sustainable marketing has nowadays a dominant role in consumer purchasing behaviour and market sales, the communication of the water-related identity of wines could be an additional driver for approaching water-sensitive market segments. To some extent, consumers and policy-makers should also become aware of the virtual water flows, particularly blue water, embedded in international wine trade, considering that agri-food trade greatly influences water appropriation in a country [43]. To this end, national initiatives and businesses in the wine sector actively engage multispectral WF mitigation initiatives to reduce operating costs and communicate the water stewardship of their products to increase consumer value. In particular, better communication to consumers could be achieved via calculating a single-score indicator for labelling purposes $[5,51]$.

In the case of the Italian wines, which are traded under the "controlled designation of origin" and "controlled and guaranteed designation of origin" labels, the adoption of water management policies can deliver a compelling marketing narrative linked to the territorial culture and history of each 
specific production wine site, promote the valorisation of local freshwater resources, and ultimately drive rural development [41]. Notably, on average, young wine consumers in Italy value water saving labelled wines and demonstrate a willingness to pay a premium price for such product offerings; determinats include wine consumption frequency, environmental-friendly attitude, label use, and label trust [5]. Therefore, as young consumers represent the most common market segment regarding wine consumption, policy-makers could act as a driving force for supporting the winemaking industry to adopt more environmental-friendly production methods (e.g., the Common Agricultural Policy of the EU [52]).

\subsection{Barriers}

Notwithstanding the pronounced need to apply water management policies and practises in the winemaking industry [46], dominant barriers hinder their adoption and maturity. The greatest peril in this process regards the poor alignment between water and agricultural policies [43], which is supported by the existence of different views among scientists regarding the system boundaries to apply water management policies (e.g., indirect WF from raw materials, transportation, end-of-life processes, etc.) $[36,37,39]$. Indicatively, Italian wines are associated with a lower WF exclusively due to the particular production specifications to guarantee designation of origin (i.e., irrigation and fertilisation are prohibited) [41]. To that effect, WF assessment methodologies generate different results even in the case that the same water management techniques are considered [35].

To a greater extent, established methodologies used for the ex ante evaluation of manufacturing operations' water impact (e.g., LCA) myopically leverage secondary data sources and neglect geographically related characteristics, such as diverse climatic conditions and applied production techniques [36,39]; thus, inconsistencies and discrepancies in the derived results are possible, but they have a detrimental effect on specific regions considering the localised supply of the embedded production inputs. At a more granular level, an evident gap in existing databases regarding indirect water consumption (e.g., green water) further raises evaluation challenges [36]. The lack of detailed data input further inhibits the contextualisation of the results in real-world operations [34], subsequently affecting the decision-making over the investments in related practises.

Furthermore, most water management-related studies focus on the academic merit of the applied methodological approaches in the pursuit of accuracy and precision of calculations. However, business stakeholders, who in principal operationalise water mitigation policies, cannot make inferences about the associated economic water productivities [42]. Moreover, the diverse alternative eco-labels for certifying the adoption of good practices for freshwater utilisation does not always provide businesses with an opportunity to differentiate from the competition [43].

\section{Discussion}

Food production and consumption are considered to have a rather detrimental impact on the environment $[39,53]$. Particularly, in the winemaking industry, sustainability is a key driver for competitiveness, market differentiation, and process innovation [4]. WF could become a meaningful indicator in sustainability initiatives for wines (as lower water consumption is also connected with a better wine quality and taste $[41,42])$; thus, the winemaking industry is exploring practises to improve the related environmental impact.

At a national level (e.g., Chile, Australia, New Zealand), frameworks to inform sustainability in the winemaking industry exist. Flores [3] reviewed the process-based winemaking frameworks in six countries and reported three categories where common water management practises are recognised: (i) soil management-protection of water resources from pollution, (ii) water management-registration of water use, selection of irrigation system, and control of water quality, and (iii) wastewater-monitoring of effluents and treatment of winery wastewater. Focussing on wastewater treatment, in countries such as France, Italy, and Spain, where the wine cellars are generally located close to urban areas, the use of advanced biological processes is crucial [54]. 
At a more granular level of operations and to cultivate grapes that result in high-quality wines, agricultural practices are required to enable the control of particular properties of grapes, such as the concentration of phenols, which determine the taste, color, and mouthfeel of wine. From a WF point of view, regulated deficit irrigation at the phenological stage is applied to increase the phenols content [27]. Alongside the different quality of the cultivated grapes for winemaking, irrigation systems and practises are also dictated by the edaphoclimatic and related infrastructure conditions at each region. Indicatively, in the province of Mendoza, Argentina, $88 \%$ of the vineyards are irrigated through surface irrigation (i.e., gravity-based systems), whereas the remaining vine-growing area is irrigated through pressurised systems (e.g., dripping) to grow wine grapes of different qualities [27]. Moreover, the selection of good practices in water management for the winemaking industry could be influenced by the assessment methodology applied [39]. Overall, this selection depends on a range of decision-making constituents. More specifically, alternative irrigation options (e.g., drip, deficit) [55,56] and wastewater treatment techniques (i.e., aerobic, anaerobic, or their combination) [54] result in different levels of water savings. In addition, the implementation of digital technologies (e.g., sensors used during viticulture) $[57,58]$ or holistic approaches for water-friendly activities across the whole wine supply chain [59] can further support an advanced and complete water stewardship plan. An indicative list of WF mitigation practices in the winemaking industry is tabulated in Table 3.

Table 3. Indicative good practices for water stewardship in the winemaking industry.

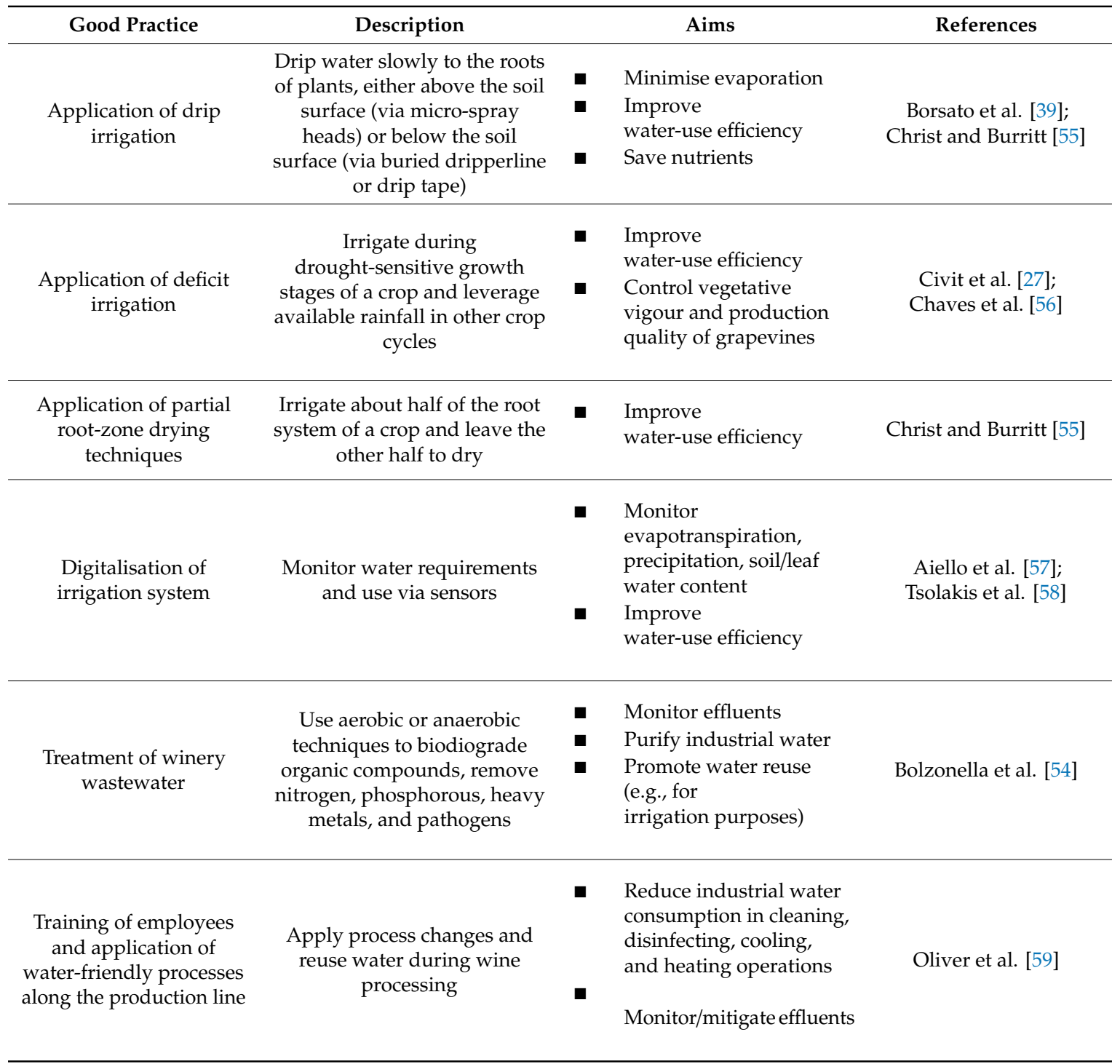




\section{Conclusions}

The Italian wine industry constitutes a global leader in terms of production quantity and quality. Within the country, the economic scale of winemaking renders the industry as the key production component of the Italian agrifood sector related to respective freshwater appropriation. To that end, the investigation of water use needs during viticulture and vinification is imperative to support water stewardship within the country's wine sector. According to the scientific literature, Italian wine dominates the research efforts with respect to WF assessment, thus validating the important role of economic and environmental sustainability in the national winemaking industry. To a greater extent, given the consumers' awareness and positive purchasing behaviour towards water-efficient wines, the sustainability profile of the Italian wines could further link to the designation of origin and receive international market's appreciation.

As research regarding water management in the winemaking industry is limited, this paper acts as an initial mapping that captures the major drivers and barriers of water stewardship considering the unique geographic and socio-economic characteristics of the Italian landscape. Our research findings indicate that the environmental, socio-economic, and market drivers outperform the existing, mainly technical and methodological, barriers. This proliferation of drivers and the identification of good practises in the industry motivate the development of operationalisable water stewardship frameworks for the Italian wine sector.

\subsection{Practical Implications}

Based on the literature evidence, it is critical that the practitioners of the Italian wine industry should act towards the direction of water management to support the preservation of freshwater resources and enhance the economic water productivity of their products. This research validates that water management policies and practices should be systematically applied in the Italian winemaking industry, from an end-to-end supply chain perspective, to enhance the sustainable brand image of the national production and foster its trade potential and market appreciation.

At an operational level, this research suggests that vine growers and winemaking practitioners should focus on water management interventions at three levels, including (i) soil management, (ii) freshwater management, and (iii) wastewater treatment [3]. In particular, we propose that the type of irrigation systems and practises to be applied should also consider the edaphoclimatic and related infrastructure conditions at each winemaking region to increase the efficiency of water resources appropriation [27]. Regarding wastewater treatment, aerobic processes (e.g., membrane bioreactors [60]) could offer an efficient and easy-to-use solution compared to anaerobic ones that constitute a more economic option [54].

To a greater extent, we propose the digitalisaiton of the wine supply chain, particularly at the farming echelon. In this regard, sensor technologies are reported to support the decision-making process concerning the water stewardship of agrifood commodities [57], which could also be pertinent to the case of the wine supply chain. The use of sensors in grapes' farming for monitor freshwater use and other related parameters (e.g., soil moisture) is an indicative digital intervention that relates to the quality of the wine production. The introduction of advanced technologies can assist in (i) mitigating methodological errors in water-use estimations, (ii) gathering field-level data, (iii) calculating water consumption in viticulture in a more accurate way, (iv) extrapolating information with regard to the WF of their supply chain, and (v) devising sound marketing strategies to engage with consumers [61].

\subsection{Future Research}

With regard to future research directions, both researchers and practitioners of the winemaking production field may focus on developing analytical and computer-based tools for multi-objective analysis and simulation to solve freshwater resource planning and operational problems. To that end, Aivazidou et al. [7] suggest a framework that guides the ex ante evaluation of applied water 
management policies through developing a pertinent simulation model that enbables the assessment of water utilisation on the supply chain financial performance. Notably, the modelling effort captures the concept of consumers' environmental sensitivity with regard to blue WF efficiency as a supply chain profitability factor. In addition, the economic evaluation of the green WF to the overall production value of wine, as inspired by the study of Grammatikopoulou et al. [9] for the case of cereals, is highly recommended considering that the majority of wine grapes across the Mediterranean are grown under rainfed conditions. To a greater extent, the economic water productivity could be combined with water scarcity indicators to account for the inter-annual variability of the green and blue WFs at a regional level to improve the management of grapes' production, supply, and wine trade in the winemaking sector [62].

To wrap up, based on the environmental, economic, and technical managerial insights obtained by the analysis of the major drivers, barriers, and good practises, it is crucial that industry stakeholders should systematically focus towards developing a concrete water management scheme in the Italian winemaking sector for fostering its sustainability.

Author Contributions: Both authors have read and agreed to the published version of the manuscript. Conceptualisation, E.A.; writing—original draft preparation, review, and editing, E.A. and N.T.; supervision, E.A. All authors have read and agreed to the published version of the manuscript.

Funding: This research received no external funding.

Conflicts of Interest: The authors declare no conflict of interest.

\section{References}

1. State of the Vitiviniculture World Market-April 2018. Available online: http://www.oiv.int/public/medias/ 5958/oiv-state-of-the-vitiviniculture-world-market-april-2018.pdf (accessed on 15 July 2019).

2. Christ, K.L.; Burritt, R.L. Water management accounting: A framework for corporate practice. J. Clean. Prod. 2017, 152, 379-386. [CrossRef]

3. Flores, S.S. What is sustainability in the wine world? A cross-country analysis of wine sustainability frameworks. J. Clean. Prod. 2018, 172, 2301-2312. [CrossRef]

4. Fiore, M.; Silvestri, R.; Contò, F.; Pellegrini, G. Understanding the relationship between green approach and marketing innovations tools in the wine sector. J. Clean. Prod. 2017, 142, 4085-4091. [CrossRef]

5. Pomarici, E.; Asioli, D.; Vecchio, R.; Næs, T. Young consumers' preferences for water-saving wines: An experimental study. Wine Econ. Pol. 2018, 7, 65-76. [CrossRef]

6. Schäufele, I.; Hamm, U. Consumers' perceptions, preferences and willingness-to-pay for wine with sustainability characteristics: A review. J. Clean. Prod. 2017, 147, 379-394. [CrossRef]

7. Aivazidou, E.; Tsolakis, N.; Vlachos, D.; Iakovou, E. A water footprint management framework for supply chains under green market behaviour. J. Clean. Prod. 2018, 197, 592-606. [CrossRef]

8. Hoekstra, A.Y.; Chapagain, A.K.; Aldaya, M.M.; Mekonnen, M.M. The Water Footprint Assessment Manual, 1st ed.; Earthscan: London, UK, 2011; ISBN 978-1-84971-279-8.

9. Grammatikopoulou, I.; Sylla, M.; Zoumides, C. Economic evaluation of green water in cereal crop production: A production function approach. Water Resour. Econ. 2019, 10048. [CrossRef]

10. Hoekstra, A.Y.; Mekonnen, M.M. The water footprint of humanity. Proc. Natl. Acad. Sci. USA 2012, 109, 3232-3237. [CrossRef]

11. Mekonnen, M.M.; Hoekstra, A.Y. The green, blue and grey water footprint of crops and derived crop products. Hydrol. Earth Syst. Sci. 2011, 15, 1577-1600. [CrossRef]

12. Lamastra, L. The Virtual Water in A Bottle of Wine. In The Water We Eat: Combining Virtual Water and Water Footprints, 1st ed.; Antonelli, M., Greco, F., Eds.; Springer International Publishing: Cham, Switzerland, 2015; pp. 209-228. ISBN 978-3-319-16392-5.

13. Gassert, F.; Reig, P.; Luo, T.; Maddocks, A. Aqueduct Country and River Basin Rankings: A Weighted Aggregation of Spatially Distinct Hydrological Indicators, 1st ed.; Working Paper; World Resources Institute: Washington, DC, USA, 2013.

14. Pfister, S.; Koehler, A.; Hellweg, S. Assessing the Environmental Impacts of Freshwater Consumption in LCA. Environ. Sci. Technol. 2009, 43, 4098-4104. [CrossRef] 
15. La Produzione di vino in Italia nel 2017-Dati Finali ISTAT. Available online: http://www.inumeridelvino.it/ 2018/05/la-produzione-di-vino-in-italia-nel-2017-dati-finali-istat.html (accessed on 15 July 2019).

16. L'agricoltura Italiana Conta 2017. Available online: http://www.condifesafoggia.it/wp-content/uploads/2018/ 01/Itaconta-2017.pdf (accessed on 15 July 2019).

17. Il Valore Della Produzione di vino nel Mondo-Stima INDV 2017. Available online: http://www. inumeridelvino.it/tag/valore-mercato-del-vino (accessed on 15 July 2019).

18. Aivazidou, E.; Tsolakis, N.; Iakovou, E.; Vlachos, D. The emerging role of water footprint in supply chain management: A critical literature synthesis and a hierarchical decision-making framework. J. Clean. Prod. 2016, 137, 1018-1037. [CrossRef]

19. Christ, K.L. Water management accounting and the wine supply chain: Empirical evidence from Australia. Br. Account. Rev. 2014, 46, 379-396. [CrossRef]

20. Hoekstra, A.Y. Water Neutral: Reducing and Offsetting the Impact of Water Footprints, 1st ed.; Value of Water Research Report Series No. 28; UNESCO-IHE Institute for Water Education: Delft, The Netherlands, 2008; ISSN 1812-2108.

21. ISO. ISO 14046:2014_Environmental Management_Water Footprint_Principles, Requirements and Guidelines; International Organization for Standardization: Geneva, Switzerland, 2014.

22. Chenoweth, J.; Hdjikakou, M.; Zoumides, C. Quantifying the human impact on water resources: A critical review of the water footprint concept. Hydrol. Earth Syst. Sci. 2014, 18. [CrossRef]

23. Herath, I.; Green, S.; Singh, R.; Horne, D.; van der Zijpp, S.; Clothier, B. Water footprinting of agricultural products: A hydrological assessment for the water footprint of New Zealand's wines. J. Clean. Prod. 2013, 41, 232-243. [CrossRef]

24. Herath, I.; Green, S.; Horne, D.; Singh, R.; McLaren, S.; Clothier, B. Water footprinting of agricultural products: Evaluation of different protocols using a case study of New Zealand wine. J. Clean. Prod. 2013, 44, 159-167. [CrossRef]

25. Steenwerth, K.L.; Strong, E.B.; Greenhut, R.F.; Williams, L.; Kendall, A. Life cycle greenhouse gas, energy, and water assessment of wine grape production in California. Int. J. Life Cycle Assess. 2015, 20, 1243-1253. [CrossRef]

26. Johnson, M.-B.; Mehvar, M. An assessment of the grey water footprint of winery wastewater in the Niagara Region of Ontario, Canada. J. Clean. Prod. 2019, 214, 623-632. [CrossRef]

27. Civit, B.; Piastrellini, R.; Curadelli, S.; Arena, A.-P. The water consumed in the production of grapes for vinification (Vitis vinifera). Mapping the blue and green water footprint. Ecol. Indic. 2018, 85, 236-243. [CrossRef]

28. Ene, S.-A.; Teodosiu, C.; Robu, B.; Volf, I. Water footprint assessment in the winemaking industry: A case study for a Romanian medium size production plant. J. Clean. Prod. 2013, 43, 122-135. [CrossRef]

29. Bujdosó, B.; Waltner, I. Water Footprint Assessment of a Winery and its Vineyard. Hung. Agr. Res. 2017, 1, 10-13.

30. Quinteiro, P.; Dias, A.-C.; Pina, L.; Neto, B.; Ridoutt, B.G.; Arroja, L. Addressing the freshwater use of a Portuguese wine ('vinho verde') using different LCA methods. J. Clean. Prod. 2014, 68, 46-55. [CrossRef]

31. Martins, A.A.; Araújo, A.R.; Morgado, A.; Graça, A.; Caetano, N.S.; Mata, T.M. Sustainability Evaluation of a Portuguese "Terroir" Wine. Chem. Eng. Trans. 2017, 57, 1945-1950. [CrossRef]

32. Villanueva-Rey, P.; Quinteiro, P.; Vánquez-Rowe, I.; Rafael, S.; Arroja, L.; Moreira, M.T.; Feijoo, G.; Dias, A.C. Assessing water footprint in a wine appellation: A case study for Ribeiro in Galicia, Spain. J. Clean. Prod. 2018, 172, 2097-2107. [CrossRef]

33. Meneses, M.; Torres, C.M.; Castells, F. Sensitivity analysis in a life cycle assessment of an aged red wine production from Catalonia, Spain. Sci. Total Environ. 2016, 562, 571-579. [CrossRef] [PubMed]

34. Lamastra, L.; Suciu, N.-A.; Novelli, E.; Trevisan, M. A new approach to assessing the water footprint of wine: An Italian case study. Sci. Total Environ. 2014, 490, 748-756. [CrossRef]

35. Bonamente, E.; Scrucca, F.; Asdrubali, F.; Cotana, F.; Presciutti, A. The Water Footprint of the Wine Industry: Implementation of an Assessment Methodology and Application to a Case Study. Sustainability 2015, 7, 12190-12208. [CrossRef]

36. Bonamente, E.; Scrucca, F.; Rinaldi, S.; Merico, M.-C.; Asdrubali, F.; Lamastra, L. Environmental impact of an Italian wine bottle: Carbon and water footprint assessment. Sci. Total Environ. 2016, 560-561, 274-283. [CrossRef] 
37. Rinaldi, S.; Bonamente, E.; Scrucca, F.; Merico, M.-C.; Asdrubali, F.; Cotana, F. Water and Carbon Footprint of Wine: Methodology Review and Application to a Case Study. Sustainability 2016, 8, 621. [CrossRef]

38. Bartocci, P.; Fantozzi, P.; Fantozzi, F. Environmental impact of Sagrantino and Grechetto grapes cultivation for wine and vinegar production in central Italy. J. Clean. Prod. 2017, 140, 569-580. [CrossRef]

39. Borsato, E.; Giubilato, E.; Zabeo, A.; Lamastra, L.; Criscione, P.; Tarolli, P.; Marinello, F.; Pizzol, L. Comparison of Water-focused Life Cycle Assessment and Water Footprint Assessment: The case of an Italian wine. Sci. Total Environ. 2019, 666, 1220-1231. [CrossRef]

40. Boulay, A.-M.; Bare, J.; Benini, L.; Berger, M.; Lathuillière, M.J.; Manardo, A.; Margni, M.; Motoshita, M.; Núñez, M.; Pastor, A.-V.; et al. The WULCA consensus characterization model for water scarcity footprints: Assessing impacts of water consumption based on available water remaining (AWARE). Int. J. Life Cycle Assess. 2018, 23, 368-378. [CrossRef]

41. Miglietta, P.-P.; De Leo, F.; Massari, S. Water footprint assessment of some Italian wines: A territorial perspective. Int. J. Environ. Policy Decis. Making 2015, 1, 320-331. [CrossRef]

42. Miglietta, P.-P.; Morrone, D.; Lamastra, L. Water footprint and economic water productivity of Italian wines with appellation of origin: Managing sustainability through an integrated approach. Sci. Total Environ. 2018, 633, 1280-1286. [CrossRef] [PubMed]

43. Miglietta, P.-P.; Morrone, D. Managing Water Sustainability: Virtual Water Flows and Economic Water Productivity Assessment of the Wine Trade between Italy and the Balkans. Sustainability 2018, 10, 543. [CrossRef]

44. EcoWater Report-Comparing Water Footprint Methods: The Importance of a Life Cycle Approach in Assessing Water Footprint. Available online: https:/www.ivl.se/download/18.343dc99d14e8bb0f58b7739/ 1445517875373/C98.pdf (accessed on 13 December 2019).

45. Hoekstra, A.Y.; Chapagain, A.K.; van Oel, P.R. Progress in Water Footprint Assessment: Towards Collective Action in Water Governance. Water 2019, 11, 1070. [CrossRef]

46. Fayolle, E.; Follain, S.; Marchal, P.; Chéry, P.; Colin, F. Identification of environmental factors controlling wine quality: A case study in Saint-Emilion Grand Cru appellation, France. Sci. Total Environ. 2019, 69, 133718. [CrossRef]

47. Vaudour, E. The quality of grapes and wine in relation to geography: Notions of terroir at various scales. J. Wine Res. 2002, 13, 117-141. [CrossRef]

48. Special Edition: Progress towards the Sustainable Development Goals. Report of the Secretary-General. Available online: https://undocs.org/E/2019/68 (accessed on 11 October 2019).

49. Rugani, B.; Vázquez-Rowe, I.; Benedetto, G.; Benetto, E. A comprehensive review of carbon footprint analysis as an extended environmental indicator in the wine sector. J. Clean. Prod. 2013, 54, 61-77. [CrossRef]

50. Lockshin, L.; Corsi, A.M. Consumer behaviour for wine 2.0: A review since 2003 and future directions. Wine Econ. Policy 2012, 1, 2-23. [CrossRef]

51. Ridoutt, B.G.; Pfister, S. A new water footprint calculation method integrating consumptive and degradative water use into a single stand-alone weighted indicator. Int. J. Life Cycle Assess. 2013, 18, 204-207. [CrossRef]

52. The Common Agricultural Policy at a Glance. Available online: https://ec.europa.eu/info/food-farmingfisheries/key-policies/common-agricultural-policy/cap-glance_en (accessed on 13 December 2019).

53. Notarnicola, B.; Tassielli, G.; Renzulli, P.A.; Castellani, V.; Sala, S. Environmental impacts of food consumption in Europe. J. Clean. Prod. 2017, 140, 753-765. [CrossRef]

54. Bolzonella, D.; Papa, M.; Da Ros, C.; Muthukumar, L.-A.; Rosso, D. Winery wastewater treatment: A critical overview of advanced biological processes. Crit. Rev. Biotechnol. 2019, 39, 489-507. [CrossRef]

55. Christ, K.L.; Burritt, R.L. Critical environmental concerns in wine production: An integrative review. J. Clean. Prod. 2013, 53, 232-242. [CrossRef]

56. Chaves, M.M.; Santos, T.P.; Souza, C.R.; Ortuño, M.F.; Rodrigues, M.L.; Lopes, C.M.; Maroco, J.P.; Pereira, J.S. Deficit irrigation in grapevine improves water-use efficiency while controlling vigour and production quality. Ann. Appl. Biol. 2007, 150, 237-252. [CrossRef]

57. Aiello, G.; Cannizzaro, L.; La Scalia, G.; Muriana, C. An expert system for vineyard management based upon ubiquitous network technologies. Int. J. Services Oper. Inform. 2011, 6, 230-247. [CrossRef]

58. Tsolakis, N.; Aivazidou, E.; Srai, J.S. Sensor applications in agrifood systems: Current trends and opportunities for water stewardship. Climate 2019, 7, 44. [CrossRef] 
59. Oliver, P.; Rodríguez, R.; Udaquiola, S. Water use optimization in batch process industries. Part 1: Design of the water network. J. Clean. Prod. 2008, 16, 1275-1286. [CrossRef]

60. Bolzonella, D.; Fatone, F.; Pavan, P.; Cecchi, F. Application of a membrane bioreactor for winery wastewater treatment. Water Sci. Technol. 2010, 62, 2754-2759. [CrossRef]

61. Van der Laan, M.; Jarmain, C.; Bastidas-Obando, E.; Annandale, J.G.; Fessehazion, M.; Haarhoff, D. Are water footprints accurate enough to be useful? A case study for maize (Zea mays L.). Agr. Water Manage. 2019, 213, 512-520. [CrossRef]

62. Zoumides, C.; Bruggeman, A.; Hadjikakou, M.; Zachariadis, T. Policy-relevant indicators for semi-arid nations: The water footprint of crop production and supply utilization of Cyprus. Ecol. Indic. 2014, 43, 205-214. [CrossRef]

(C) 2020 by the authors. Licensee MDPI, Basel, Switzerland. This article is an open access article distributed under the terms and conditions of the Creative Commons Attribution (CC BY) license (http://creativecommons.org/licenses/by/4.0/). 